\title{
From Laggards to Leaders
}

\author{
The Evolving Role of the Private Actors in the International Climate Regime
}

\author{
Charlotte Streck
}

\section{Introduction}

In December 2015, thousands of negotiators representing almost two hundred countries agreed the terms of the Paris Agreement, ${ }^{1}$ thereby establishing a new long-term cooperative framework to address global climate change. Compared to other climate conferences, the Paris summit was characterized by a spirit of cooperation and willingness to compromise. However, the event was also remarkable in other ways: never before had the private sector assumed such a public and visible role organizing events alongside the official negotiations. According to the website of the United Nations Framework Convention on Climate Change (UNFCCC or Convention), one third of the 2,ooo biggest global companies committed to climate action in Paris. ${ }^{2}$ Together these companies comprised a market value equivalent to the combined gross-domestic product of China, Germany and Japan. ${ }^{3}$ The interest of the private sector in climate negotiations has grown in parallel with the elevation of climate change to a policy topic of high global priority. While early climate conferences were of principal concern to environmental policy makers and environmental groups, they have now become global events that attract heads of States, corporate leaders, religious dignitaries and pop stars, in addition to representatives of non-governmental organizations (NGOs), members of the scientific communities and experts. ${ }^{4}$

1 Paris Agreement, adopted 12 December 2015, in force 4 November 2016, [2016] ATS 24.

2 United Nations Climate Change, 'Massive Mobilization by Non-State Stakeholders Summarized at COP21' Press Release (5 December 2015), https://unfccc.int/news/massivemobilization-by-non-state-stakeholders-summarized-at-cop21; accessed 5 July 2019.

3 Ibid.

4 L Partzsch, 'Take Action Now: The Legitimacy of Celebrity Power in International Relations' (2018) 24(2) Global Governance: A Review of Multilateralism and International Organizations 229-248. 
The UN climate regime has evolved since the adoption of the UNFCCC 5 in Rio de Janeiro in 1992 to encompass two affiliate legal agreements - the Kyoto Protocol ${ }^{6}$ and the Paris Agreement - alongside hundreds of UNFCCC decisions regulating everything from carbon accounting to the approval of private sector mitigation projects. ${ }^{7}$ Previously, private actors focused their efforts on lobbying to ensure that their interests were represented in formal legal texts of the UNFCCC and the Kyoto Protocol. The Kyoto Protocol involved private entities into its regulatory system by assigning them roles as financiers, implementers and auditors while operationalizing the Protocol's carbon market mechanisms. ${ }^{8}$ Today, non-State actors, that is, NGOs and corporations, and subnational public entities such as cities or States, have moved beyond formally assigned roles of the regime and become essential agents of treaty implementation. ${ }^{9}$ Governments more and more rely on private entities to identify and implement mitigation and adaptation measures. Green (and sometimes notso-green) businesses increasingly use the attention and media focus of international climate events to showcase climate-friendly projects, investments and multi-sectoral and transnational partnerships. ${ }^{10}$ Businesses also embrace the opportunity to share the stage with governments and NGOs to present joint public/private initiatives, ${ }^{11}$ which often blur the fault-lines between the traditional roles of private and public sectors under the climate regime.

$5 \quad$ Adopted 9 May 1992, in force 21 March 1994, 1771 UNTS 107.

6 Kyoto Protocol to the United Nations Framework Convention on Climate Change (UNFCCC), adopted 11 December 1997, in force 16 February 2005, 2303 UNTS 162.

7 The Decisions adopted under the UnfCcc, the Kyoto Protocol, and the Paris Agreement can be accessed on the website of the UNFCCC Secretariat: https://unfccc.int/decisions; accessed 5 July 2019.

8 C Streck, 'Joint Implementation: History, Requirements, and Challenges' in C Streck and D Freestone (eds), Legal Aspects of Implementing the Kyoto Protocol Mechanisms (Oxford University Press, 2005); C Streck and D Freestone, 'Summary and Outlook' in D Freestone and C Streck (eds), Legal Aspects of Carbon Trading: Kyoto, Copenhagen and beyond (Oxford University Press, 2009).

9 K Bäckstrand, JW Kuyer, B Linnér and E Lövbrand, 'Non-State Actors in Global Climate Governance: From Copenhagen to Paris and Beyond'(2017) 26(4) Environmental Politics 561-579; M Paterson, 'Networks and Coordination in Global Climate Governance' in The Paris Agreement and Beyond: International Climate Change Policy Post-2020 (Harvard Project on Climate Agreements, 2016); LB Andonova, M Betsill, and H Bulkeley, 'Transnational Climate Governance' (2009) 9(2) Global Environmental Politics 52-73.

10 H Schroeder and H Lovell, 'The Role of Non-nation-State Actors and Side Events in the International Climate Negotiations' (2011) 12(1) Climate Policy 23-37; M Hjerpe and B Linnér, 'Functions of COP Side-events in Climate-change Governance' (2011) 10(2) Climate Policy $167-18$ o.

11 A Pinz, N Roudyani, and J Thaler, 'Public-private Partnerships as Instruments to Achieve Sustainability-related Objectives: The State of the Art and a Research Agenda' (2018) 20(1) 
Private actors also take the centre stage where nation States cannot, will not or are to slow to act. 'America's Pledge' on climate change, which - in direct reaction to the decision of the US Government to withdraw from the Paris Agreement - brings together private and public sector leaders committed to meeting the country's climate goals in line with the Paris Agreement. ${ }^{12}$ In July 2019, the UNFCCC-hosted 'Non-State Actor Zone for Climate Action' (NAZCA) recorded 12,648 climate-commitments by 9,378 cities, 126 regions, 2,483 companies, 363 investors and 118 civil society organizations, ${ }^{13}$ making the non-State venues of international climate meetings decisively more vibrant than the formal negotiation space.

The emergence of a great number and great variety of climate pledges, but also private standards and codes-of-conduct, directly and indirectly influences the rule-making under the climate regime. Private initiatives can formulate and pioneer rules in smaller settings or with a particular geographic focus. Where such rules become reference standards for other initiatives they are likely to serve also as model rules for formal regulation and law making. ${ }^{14}$ This is true for the national as much as for the international context where private or private-public transnational networks increasingly design templates for regulative frameworks on how to cooperatively solve a particular problem. ${ }^{15}$ The bottom-up flexible architecture of the Paris Agreement responds to this development by replacing a rigid system of carbon market mechanisms with a space for a multitude of private (for profit and non-for profit) initiatives and networks (private and public-private) to harness private engagement. This reflects the ever-growing expectation that the private sector will come up with the sort of ambition governments continue to be found lacking. However,

Public Management Review (Special Issue: Sustainable Public Management, NM Boyd and EC Martin (eds)) 1-20; A Gardiner, M Bardout, F Grossi and S Dixson-Declève, PublicPrivate Partnerships for Climate Finance (Nordic Council of Ministers, 2015); P Pattberg, 'Public-private Partnerships in Climate Governance' (2010) 1 WIREs Climate Change 279-287.

12 'America's Pledge', https://www.americaspledgeonclimate.com; accessed 5 July 2019.

13 UnfCcc, 'Global Climate Action', http://climateaction.unfccc.int; YaLE Data-Driven Environmental Solutions Group, Taking Stock of Global Climate Action (Yale Data-Driven, 18 November 2016), https://datadrivenlab.org/wp-content/uploads/2016/12/Data Driven_Yale_Taking-Stock-of-Global-Climate-Action_Nov_2016_final.pdf; accessed 2 October 2020.

14 A Peters, T Föster and L Koechelin, 'Towards Non-State Actors as Effective, Legitimate, and Accountable Stander-setters' in A Peters, L Koechlin, T Forster, GF Zinerknagel (eds), Non-State Actors as Standard Setters (Cambridge University Press, 2009) 492-562.

15 S Guéneau, 'Certification as New Private Global Forest Governance System: The Regulatory Potential of the Forest Stewardship Council' in Peters et al. (eds), ibid 379-408. 
the pendulum may have swung too far in conjuring corporate engagement as the Paris Agreement gives private initiative surprisingly little programmatic guidance and under scrutiny there remains little regulatory space in the Paris Agreement for non-State actors to gain hold. ${ }^{16}$

This chapter takes these developments as occasion to discuss the changing role of private actors in the climate regime. It reviews the implications of increased private engagement, including a shift of responsibility to achieve climate goals and regulatory border crossing from public to private actors. It also aims to shed light on the evolving and multi-faceted role of the non-State actors in the climate regime. Describing the integration of private and public initiatives into the governance of the Paris Agreement, this chapter draws attention to the opportunities and challenges facing increasingly multipolar and hybrid climate governance. It concludes with discussing how private initiatives influence public rule making and how the effectiveness of non-State initiatives can be further strengthened by anchoring them in the formal negotiation track of the Paris Agreement.

The UNFCCC recognizes the role of private actors and allows their participation in the international climate regime. The Convention addresses the role of non-governmental entities in supporting climate education, training and public awareness ${ }^{17}$ in authorizing the Secretariat to the Convention to use the services, cooperation, and information provided by, among others, NGO experts; ${ }^{18}$ and in allowing NGOs to participate as observers in meetings of States parties. ${ }^{19}$ The Kyoto Protocol reiterates this right, ${ }^{20}$ and mandates the parties to seek non-governmental support to promote the Protocol's effective implementation. ${ }^{21}$ In addition, the Protocol assigns an explicit role to the private sector when it authorizes its participation in Clean Development Mechanism $(\mathrm{CDM})^{22}$ and Joint Implementation $(\mathrm{JI})^{23}$ project activities, and emphasizes

\footnotetext{
16 C Streck, M von Unger, N Krämer, 'From Paris to Katowice: COP-24 Tackles the Paris Rulebook' (2019) 16(2) Journal for European Environmental and Planning Law 165-19o.

17 UNFCCC, above (n 5), Art 4(1)(i).

18 Ibid Art 7(2)(i).

$19 \operatorname{Ibid} \operatorname{Art} 7(6)$.

$20 \quad$ Kyoto Protocol, above (n 6), Art 13(8).

21 Ibid Art 13(4)(i).

22 Ibid Art 12(9).

23 Ibid Art 6(3).
} 
its role in the transfer of environmentally sound technologies. ${ }^{24}$ The CDM and JI mechanisms harness the financial and operational abilities of the private sector to generate emission reductions which can be transferred to States for compliance with their obligations under the Kyoto Protocol. Thus, the Kyoto Protocol enables the participation of private entities in international, regulated carbon markets by allowing them to generate, finance or acquire tradable emission reductions.

The Paris Agreement adds enthusiasm to the relationship and broadly embraces non-State actors, including subnational bodies, by affirming, in its preamble, the importance of 'public participation' and of 'engagements' with 'all levels of government and various actors' 25 to achieve the goals of the Agreement. More specifically, it formulates a mechanism of international cooperation that carries over features of the CDM and JI into the new accord. The Agreement, in Article 6(4), defines a mechanism that aims to 'incentivize and facilitate participation in the mitigation of greenhouse gas emissions (GHG) by public and private entities authorized by a Party. ${ }^{26}$ The article allows parties or authorized private or public entities to generate emission reductions and support activities that promote mitigation and sustainable development. Although lessons from the Kyoto Protocol's CDM may prove useful and constructive in devising the necessary rules and tools (such as a common registry and a standard reporting format for units), the new mechanism will have to go beyond offsetting and result in overall mitigation. ${ }^{27}$ Article 6(8) of the Agreement provides for the inclusion of private entities in non-market approaches.

The parties adopting the Paris Agreement also explicitly agreed 'to uphold and promote regional and international cooperation in order to mobilize stronger and more ambitious climate action by all parties and non-party stakeholders, including civil society, the private sector, financial institutions, cities and other subnational authorities, local communities and indigenous peoples'.28

The Paris Agreement remains vague on how ambitious climate action by non-State actors should be incentivized, and one has to turn to the Decision on the Adoption of the Paris Agreement - a text of less regulatory force and legal consequence - for additional programmatic guidance. The decision welcomes 'the efforts of all non-Party stakeholders to address and respond to climate change, including those of civil society, the private sector, financial

\footnotetext{
24 Ibid Art 1o(c).

25 Paris Agreement, above (n 7), Preamble.

26 Ibid Art 6(4).

27 Ibid Art 6(4)(c).

28 Ibid Preamble.
} 
institutions, cities and other subnational authorities, ${ }^{29}$ and encourages them to register those actions in the NAZCA platform. ${ }^{30}$ While public and private actors have responded to this invitation, it remains unclear how the drafters of the Paris Agreement envisioned the so-desired and needed integration of private and sub-national public actors into the Agreement's regulatory framework. An invitation to register efforts is functionally a very modest step to anchor private action into the Agreement.

\section{Roles of Non-State Actors in the Climate Regime}

A range of observers attend international climate talks and represent private and non-State public sectors. To attend official climate negotiations all private participants, including businesses, have to be accredited by a non-for-profit entity. Businesses often accredit by industry organizations (e.g., the World Business Council for Sustainable Development ${ }^{31}$ or the International Emissions Trading Organization ${ }^{32}$ ). The participation of NGOs 'allows vital experience, expertise, information and perspectives from civil society to be brought into the process to generate new insights and approaches' and 'promotes transparency'.33 Such participation is consistent with international practice and norms, ${ }^{34}$ and experience from international processes which affirm that the best decisions are made when civil society participates. Accredited NGO s represent a broad spectrum of interests ranging from representatives of industry

29 UNFCC, 'Decision 1/CP21: Adoption of the Paris Agreement', Report of the Conference of the Parties on its twenty-first session, held in Paris from 30 November to 13 December 2015, UN Doc FCCC/CP/2015/10/Add.1 (29 January 2016), para 133.

30 Ibid., paras 117, 134. See also Non-State Actor Zone for Climate Action (NAZCA) website, http://climateaction.unfccc.int; accessed 5 July 2019.

31 See World Business Council for Sustainable Development website, https://www.wbcsd. org; accessed 5 July 2019.

32 See International Emissions Trading Organization website, https://www.ieta.org; accessed 5 July 2019.

33 UNFCCC, 'Guidelines for the participation of representatives of non-governmental organizations at meetings of the bodies of the United Nations Framework Convention on Climate Change' (2003), https://unfccc.int/sites/default/files/coc_guide.pdf; accessed 5 July 2019 .

34 Rio Declaration on Environment and Development, UN Doc A/CONF.151/26 (Vol I) (12 August 1992), Annex 1, Principle 10; Agenda 21, UN Doc A/CONF.15/26 (Vol 1) (12 August 1992), Annex II, paras 27.3 and 27.4; Convention on Access to Information, Public Participation in Decision-Making and Access to Justice in Environmental Matters, adopted 25 June 1998, in force 30 October 2001, 2161 UNTS 447. 
to smallholder farmers. ${ }^{35}$ The following section will briefly describe the actors, roles and interests represented at UN climate talks. Table 3.1 summarizes these findings (see below).

\subsection{Non-State Observers at UN Climate Talks}

As of 2018, over 2,200 different interest groups and organizations were registered as official UNFCCC observer organizations. ${ }^{36}$ These organizations are grouped in various constituencies that act as loose groupings which have emerged from the accredited observers in order to facilitate interaction. ${ }^{37}$ They can broadly be divided into private and public observer groups. Private sector groups include representatives from environmental non-for-profit organizations (ENGOS), business and industry NGOS (BINGOS), researchbased organizations, that is, research and independent NGOs (RINGOs), as well as representatives from farmer organizations, indigenous peoples, trade unions, or women's and youth groups. Public sector groups include international organizations and sub-national entities, such as cities and regions, in addition to national governments that are accredited as parties to the Convention.

ENGOS are the most emblematic civil society representatives at climate talks. They have a long-standing presence at climate negotiations and represent more than 1,500 registered organizations. They accredit almost 40 percent of non-governmental observers. ${ }^{38}$ Primarily motivated to attend the events and push for ambitious outcomes, ENGO s have been part of climate talks from their interception. They bring a wealth of historical memory to the events, and some of the experts most versed in the complex mechanics of climate negotiations come from ENGO s. As such they seek access to party delegations as members in order to pursue their goals effectively and to directly exert

35 UNFCCC, 'Synthesis Report on Ways to Enhance the Engagement of Observer Organizations, Note by the Secretariat', UN Doc FCCC/sBI/2010/16 (19 October 2010), para 6.

36 See UNFCCC statistics website, https://unfccc.int/process-and-meetings/parties-nonparty-stakeholders/non-party-stakeholders/statistics-on-non-party-stakeholders; accessed 5 July 2019.

37 UNFCCC Synthesis Report, above (n 35$)$.

38 UNFCCC statistics, above (n 36). In 2017, environmental groups sent 37.6 percent of the total non-party observers to COP (excluding observers from international organizations), research organizations 27.1 percent and business NGO 15.8 percent. Not showing in these statistics are those private sector representatives attending events that are organized at the sidelines of large climate conferences. 
TABLE 3.1 Actors and their roles in the international climate regime

\begin{tabular}{|c|c|c|c|c|}
\hline Actors & $\begin{array}{l}\text { Characteristics } \\
\text { of the function }\end{array}$ & Interest & Roles & Examples \\
\hline $\begin{array}{l}\text { Public: } \\
\text { International } \\
\text { organizations }\end{array}$ & $\begin{array}{l}\text { Representing } \\
\text { implementation } \\
\text { capacity; } \\
\text { providing } \\
\text { expertise }\end{array}$ & $\begin{array}{l}\text { Managing } \\
\text { climate finance } \\
\text { contributions; } \\
\text { implementing } \\
\text { climate } \\
\text { solutions }\end{array}$ & $\begin{array}{l}\text { Offering their } \\
\text { institutions as } \\
\text { implementation } \\
\text { agents; supporting } \\
\text { weaker countries } \\
\text { in reacting to } \\
\text { climate change }\end{array}$ & $\begin{array}{l}\text { UNDP, United } \\
\text { Nations } \\
\text { Environment } \\
\text { Programme; } \\
\text { World Bank; } \\
\text { regional } \\
\text { development } \\
\text { banks }\end{array}$ \\
\hline
\end{tabular}

\begin{tabular}{|c|c|c|c|c|}
\hline $\begin{array}{l}\text { Public: } \\
\text { Subnational } \\
\text { jurisdictions }\end{array}$ & $\begin{array}{l}\text { Representing } \\
\text { implementation } \\
\text { capacity; agenda } \\
\text { setting }\end{array}$ & $\begin{array}{l}\text { Highlighting } \\
\text { their existing } \\
\text { or future } \\
\text { contributions } \\
\text { to climate } \\
\text { change } \\
\text { mitigation and } \\
\text { adaptation; } \\
\text { access to } \\
\text { expertise and } \\
\text { networks }\end{array}$ & $\begin{array}{l}\text { Connecting } \\
\text { with other } \\
\text { jurisdictions; } \\
\text { participating in } \\
\text { networks and } \\
\text { public-private } \\
\text { partnerships; } \\
\text { endorsing } \\
\text { of pledges } \\
\text { and public } \\
\text { commitments }\end{array}$ & $\begin{array}{l}\text { Cities and } \\
\text { regions, often } \\
\text { represented } \\
\text { through city } \\
\text { networks }\end{array}$ \\
\hline $\begin{array}{l}\text { Private, for } \\
\text { profit: } \\
\text { Corporations } \\
\text { that provide } \\
\text { solutions } \\
\text { addressing } \\
\text { climate change }\end{array}$ & $\begin{array}{l}\text { Representing } \\
\text { implementation } \\
\text { capacity; } \\
\text { lobbying and } \\
\text { influencing; } \\
\text { providing } \\
\text { expertise }\end{array}$ & $\begin{array}{l}\text { Long-term, } \\
\text { predictable, } \\
\text { rules within } \\
\text { an ambitious } \\
\text { climate regime }\end{array}$ & $\begin{array}{l}\text { Implementing } \\
\text { climate } \\
\text { solutions; part } \\
\text { of public-private } \\
\text { partnerships } \\
\text { that cooperate in } \\
\text { implementation; } \\
\text { support } \\
\text { of pledges } \\
\text { and global } \\
\text { commitments }\end{array}$ & $\begin{array}{l}\text { Renewable } \\
\text { energy } \\
\text { companies; } \\
\text { companies } \\
\text { that promote } \\
\text { low-carbon } \\
\text { transport or } \\
\text { zero-energy } \\
\text { housing }\end{array}$ \\
\hline
\end{tabular}


TABLE 3.1 Actors and their roles in the international climate regime (cont.)

\begin{tabular}{llll}
\hline Actors & $\begin{array}{l}\text { Characteristics } \\
\text { of the function }\end{array}$ & Roles & Examples
\end{tabular}

\begin{tabular}{|c|c|c|c|c|}
\hline $\begin{array}{l}\text { Private, for } \\
\text { profit: } \\
\text { Corporations } \\
\text { that are } \\
\text { negatively } \\
\text { affected by } \\
\text { climate action }\end{array}$ & $\begin{array}{l}\text { Lobbying and } \\
\text { influencing }\end{array}$ & $\begin{array}{l}\text { Avoiding } \\
\text { or delaying } \\
\text { action; } \\
\text { maintenance } \\
\text { of the status } \\
\text { quo }\end{array}$ & $\begin{array}{l}\text { Participation } \\
\text { in networks } \\
\text { that look at } \\
\text { weakening } \\
\text { climate action }\end{array}$ & $\begin{array}{l}\text { Fossil-fuel } \\
\text { sourcing and } \\
\text { dependent } \\
\text { businesses }\end{array}$ \\
\hline
\end{tabular}

Private, non-for- Awareness- Long-term, Presenting their International profit: ENGOS raising and predictable, activities and and national agenda-setting; rules within recruitsupport environmental lobbying and an ambitious for their mission; groups (World influencing; climate regime mobilize Wildlife Fund, holding accountable; donations; serving as providing resource to expertise negotiators

\begin{tabular}{|c|c|c|c|c|}
\hline $\begin{array}{l}\text { Private, non-for- } \\
\text { profit: Research } \\
\text { organizations }\end{array}$ & $\begin{array}{l}\text { Awareness- } \\
\text { raising and } \\
\text { agenda-setting; } \\
\text { holding } \\
\text { expertise; } \\
\text { holding } \\
\text { accountable }\end{array}$ & $\begin{array}{l}\text { Science-based } \\
\text { approach } \\
\text { towards rule } \\
\text { making }\end{array}$ & $\begin{array}{l}\text { Presenting } \\
\text { scientific } \\
\text { updates; } \\
\text { participation in } \\
\text { the IPCC; serving } \\
\text { as resource to } \\
\text { negotiators }\end{array}$ & $\begin{array}{l}\text { Universities; } \\
\text { think tanks }\end{array}$ \\
\hline $\begin{array}{l}\text { Private, non-for- } \\
\text { profit: Youth, } \\
\text { gender, faith- } \\
\text { based, and other } \\
\text { NGO s }\end{array}$ & $\begin{array}{l}\text { Awareness- } \\
\text { raising and } \\
\text { agenda-setting }\end{array}$ & $\begin{array}{l}\text { Ensuring a } \\
\text { representation } \\
\text { of interests } \\
\text { and points } \\
\text { of views } \\
\text { in climate } \\
\text { solutions }\end{array}$ & $\begin{array}{l}\text { Ensuring the } \\
\text { understanding } \\
\text { and appreciation } \\
\text { of their core } \\
\text { mission and its } \\
\text { link with climate } \\
\text { change }\end{array}$ & $\begin{array}{l}\text { Churches; } \\
\text { indigenous } \\
\text { peoples } \\
\text { groups; } \\
\text { women's } \\
\text { groups; human } \\
\text { rights groups }\end{array}$ \\
\hline
\end{tabular}


influence on policy makers. ${ }^{39}$ Such integration into government delegations greatly increases the access and influences of ENGOS as it erodes the difference between public and private delegation members. Over the years, the NGO community, which traditionally focused on pushing for ambitious climate mitigation efforts, has seen an increased participation of development NGO s that are concerned about the impact of climate change on the world's poorest and most vulnerable populations.

Universities and think tanks operating under the umbrella of RINGOs take the opportunity of climate conferences to present new data, studies and findings, generally also with the goal to spur action. ${ }^{40}$ They attend climate conferences in high numbers, ranking second after ENGOs in participation. Researchers have strong cognitive power ${ }^{41}$ and high standing at climate conferences. The link of the climate regime to the Intergovernmental Panel on Climate Change (IPCC) which brings together the world's leading climate researchers increases their formal recognition and gives them the opportunity to inform the negotiations through official channels.

Businesses send an increasingly large delegation of participants to climate negotiations. They are accredited by BINGOs and represent a wide range of interests depending on their business purpose. This group comprises the world's largest emitters as well as small consultancies or technical solutionproviders. What unites them and marks the difference to ENGOs is that they primarily pursue private rather than public goals. ${ }^{42}$ Consequently, representatives of the private sector seek to influence negotiations in a way that avoids harm (e.g. oil or motor companies) or benefits (renewable energy companies, consultancies) their respective business models. Businesses see themselves as important agents in taking mitigation action, ${ }^{43}$ which leads them to claim influence in negotiations and implementation partnerships.

Other special interest groups are mostly concerned with representing marginalized groups and the impacts that climate change has on their particular constituency. Labour organizations worry about the impacts of climate change and resulting policies on workers. Indigenous peoples' representatives

39 T Böhmelt, 'Civil Society Lobbying and Countries' Climate Change Policies: A Matching Approach' (2013) 13(6) Climate Policy 698-717.

40 See Intergovernmental Panel on Climate Change (IPCC) website, http://www.ipcc.ch; accessed 5 July 2019 .

41 N Nasiritousi, M Hjerpe and B Linnér, 'The Roles of Non-State Actors in Climate Change Governance: Understanding Agency through Governance Profiles' (2016) 16(1) International Environmental Agreements: Politics, Law and Economics 109-126.

42 Ibid.

43 Ibid. 
are concerned about the adverse effects of climate change on their livelihoods and the integrity of their forested territories, which account for 20 percent of global tropical forest carbon reserves. ${ }^{44}$ Women's and youth groups are helping to ensure due recognition of gender issues and impacts on future generations. Faith-based groups are driven to attend by religious and ethical concerns.

Non-State public sector representatives include those from supra- and subnational governance levels, that is, international and regional organizations, and local and municipal entities. Most accredited international organizations form part of the family of UN organizations, such the UN Development Programme (UNDP) or the Food and Agriculture Organization of the United Nations (FAO). Together there are more than 100 accredited international agencies under the UNFCCC, ${ }^{45}$ whose mandate intersects with climate concerns in different ways. Many of these organizations support the negotiation process by assisting weaker countries and delegations through training and capacity building. They also support the process by gathering data and building the evidence base for action. Specialized international organizations such as the World Meteorological Organization and the IPCC bring together essential research. International finance organizations, such as the World Bank or regional development banks, play important roles as they support developing countries in financing and implementing climate programmes.

Subnational organizations, such as cities, federal states or provinces, have increased both in visibility and influence over the last years as observers of climate negotiations. An increasing number of sub-national public officials travel to climate events to publicly affirm their proactive commitment to curbing and mitigating the effects of climate change. In doing so they often challenge the authority of their national government as they wish to be seen as more proactive in exercising climate leadership. Attending the Paris conference were observers from the States and Regions Alliance, a network of 39 governments accounting for 368 million people and 2.9 gigatons of carbon dioxide emissions. ${ }^{46}$ Subnational public sector actors also take the opportunity to promote policies and measures and forge closer ties with partner jurisdictions. For example, the city alliance $\mathrm{C}_{4} \mathrm{O}$ brings together the world's

44 The Woods Hole Research Center and the Environmental Defense Fund, Tropical Forest Carbon in Indigenous Territories: A Global Analysis (2015), http://www.edf.org/sites/ default/files/tropical-forest-carbon-in-indigenous-territories-a-global-analysis.pdf; accessed 5 July 2019 .

45 UNFCCC statistics, above (n 36 ).

46 The Climate Group, 'States and Regions Alliance', https://www.theclimategroup.org/ StatesandRegions; accessed 4 July 2019. 
megacities committed to addressing climate change and helps cities to collaborate, share knowledge and drive sustainable action on climate change. ${ }^{47}$ The Carbon Neutral Cities Alliance - established in partnership with $\mathrm{C}_{4} \mathrm{O}$ - goes a step further when it brings together cities that pledge to achieve long-term carbon neutrality goals. ${ }^{48}$

\subsection{Interests and Roles of Non-State Actors}

International climate negotiations remain State-centric. States are the principal actors negotiating the rules to which they subsequently agree to submit themselves. ${ }^{49}$ International law rarely regulates the behaviour of private entities or individuals. However, private and public non-State actors have an interest in the outcome of the negotiations, an interest that, while certainly not equal to that of States, is sufficient for those actors to participate in the formation, implementation and even the enforcement of international law. ${ }^{50}$ The interest of non-State actors in international law is not new. Charnovitz's work on the long history of NGO participation in international governance provides an account of the profound influence that non-State actors have had on the scope and rules of international law. ${ }^{51}$ However, what is new is the variety of interest and geographical range of actors, as well as the increasing ease with which States call and rely on those actors for achieving important treaty outcomes. The power on which the agency of these actors rests varies depending on the category of interest of actors, between moral (legitimacy), cognitive (knowledge, expertise), leverage (access to decision-makers), and material (access to operational and financial resources) powers. ${ }^{52}$ Equipped with these sources of influence, they set out to raise awareness and lobby for certain topics; to provide expertise and hold States accountable. They also represent implementation capacity, and through the combined force of knowledge,

47 C40 Cities, 'About', http://www.c40.org/about; accessed 5 July 2019.

48 The partnering cities have committed to cut emissions by at least 80 percent by 2050 . See Carbon Neutral Cities Alliance (CNCA) website, https://carbonneutralcities.org/cities/, accessed 2 October 2020.

49 A Cassese, International Law (2nd ed, Oxford University Press, 2005) 3.

50 J Lin and C Streck, 'Mobilising Finance for Climate Mitigation: Private Sector Involvement in International Carbon Finance Mechanism' (2009) 10(1) Melbourne Journal for International Law; DB Hollis, 'Private Actors in Public International Law: Amicus Curiae and the Case for the Retention of State Sovereignty' (2002) 25(2) Boston College International and Comparative Law Review 235-255, 237.

51 S Charnovitz, 'Two Centuries of Participation: NGOs and International Governance' (1997) 18(2) Michigan Journal of International Law 183-286, 266.

$5^{2}$ Modified from N Nasiritousi, M Hjerpe, and B Linner, above (n 41). 
leverage and implementation, they increasingly also influence the regulatory functions of the climate regime.

Awareness-raising and agenda-setting. Observer organizations play an important role in climate talks raising awareness about the threats of climate change in general, but also - as the regime evolves - about particular subproblems or agenda items (e.g., particular sources of emissions, vulnerabilities of States, regions, or populations, or the role of oceans, just to name a few). One of the main roles of ENGOS is to identify emerging issues and push them onto the official negotiation agenda. Civil society groups have also taken on the role of representing marginalized people, such as indigenous peoples, as well as giving women or youth a voice where they may not be otherwise heard. They are also generally well informed and coordinate through international partnerships and networks, often more effectively than national delegations and States. ${ }^{3}$

Lobbying and influencing. Private actors also seek to influence negotiation outcomes to achieve direct or indirect benefits. Business influence is exercised in overlapping and complex ways, through formal and informal interventions, public and private arenas, and through traditional means of lobbying, as well as through market and structural power. ${ }^{54}$ In the first decade of climate negotiations, corporations positioned themselves in opposition to climate change regulation, which they saw as a threat to their competitiveness. ${ }^{55}$ Today, an increasing number of corporations promote the future-looking approach that considers climate and energy regulation as an opportunity for growth and profit, which benefits from strong legal frameworks. ${ }^{56}$

As business interests have become more diverse, interventions have become more multi-layered. For many years, delegations of oil-exporting nations, most notably Saudi Arabia, have closely cooperated with the fossil fuel industry to obstruct climate talks. ${ }^{57}$ In contrast, pro-climate change businesses, such as

53 Ibid.

54 J Clapp and J Meckling, 'Business as a Global Actor' in R Faulkner (ed.), Global Handbook of Global Climate and Environment Policy (John Wiley \& Sons Ltd, 2013) 286-303.

55 Ibid.

56 Ibid.

57 J Depledge and F Yamin, 'Striving for No: Saudi Arabia in the Climate Change Regime' (2009) 8(4) Global Environmental Politics 9-35. Change may be on the horizon: In 2015, Aramco, the Saudi oil company, joined the Oil and Gas Climate Initiative, which is committed to the Paris Climate Agreement (see Oil and Gas Climate Initiative website, http:// www.oilandgasclimateinitiative.com; accessed 5 July 2019). J Legett describes the Carbon Club and affiliated organizations, such as the World Climate Council, as a network of coal, oil and other fossil-fuel-related industry umbrella groups that sought to derail international climate talks in his book, The Carbon War (Penguin, 1990). 
renewable energy providers, technology companies, and impact investors, use climate conferences to lobby for stronger targets, increased financial pledges and climate rules advantageous to their particular line of business.

ENGOS, research institutions, and civil society groups - joined by pro-active business coalitions - provide a counter-weight to forces that seek to slow progress in international climate talks. While private sector lobbyists generally prefer to act behind the scenes, environmental groups act in the open, often relying on public campaigns and broader advocacy. However, the opportunities for non-party actors to directly influence international climate negotiations during global climate summits have diminished over the years. As UNFCCC conferences draw larger and larger crowds of people, side-events hosted by observers and parties are increasingly separated from the venues of official delegations. This makes permutations between the official and non-official events increasingly difficult, allowing negotiators to go about their business with more tranquility, but limiting the opportunity of direct interaction between observers and parties. ${ }^{58}$ In reaction to the increasingly complex setting, most of the direct lobbying happens before and after the official climate negotiations.

Holding State parties accountable. NGO s may also hold climate negotiators responsible for unambitious or missed climate targets. ${ }^{59}$ The long memory of civil society ensures that governments and increasingly industry pledging action or finance are reminded of the ensuing need to take action. The climate regime defines the processes and standards that enable NGOs (and governments) to assess whether the climate regime is moving in the desired direction. ${ }^{60}$ NGOs can help to hold national governments accountable by providing critical perspectives on national GHG reporting. ${ }^{61}$ They also monitor progress towards climate goals, whether formally registered under the UNFCCC, the Kyoto Protocol or the Paris Agreement, or pledged alongside formal processes. ${ }^{62}$ This function is likely to become more relevant under the

$5^{8} \quad \mathrm{COP}^{-23}$ in Fiji/Bonn for the first time allocated accreditations limited to a stakeholder zone that did not allow entry to the negotiation space.

59 J Brunnée, 'International Legal Accountability through the Lens of the Law of State Responsibility' (2005) 36 Netherlands Yearbook of International Law $3-38$.

6o O Widerberg and P Pattberg, 'Accountability Challenges in the Transnational Regime Complex for Climate Change' (2017) 34(1) Review of Policy Research 68-87.

$61 \mathrm{H}$ van Asselt, 'The Role of Non-State Actors in Reviewing Ambition, Implementation, and Compliance under the Paris Agreement' (2016) 6(1-2) Climate Law 91-108.

62 For example, the New York Declaration on Forests (NYDF) is a public-private pledge to end tropical deforestation (https://nydfglobalplatform.org). The Tropical Forest Alliance 2020 is a public-private network seeking to further the implementation of the NYDF (https:// www.tfa2020.org/en/), and the NYDF Assessment Partners is a civil society initiative to 
Paris Agreement, which is based on the premise that with increased transparency and a strong overall target, countries will step forward with increasingly ambitious national plans. Non-State actors are set to act as watchdogs of implementation progress towards national climates pledges, the 'nationally determined contributions' (NDCs); they will help to enhance transparency and facilitate the stocktakes, and finally it will fall upon them to press for the ratcheting up of NDCs every five years. ${ }^{63}$

Providing expertise. From their inception, climate negotiations have had a strong link with researchers and universities. While this has not protected them from the attacks of climate sceptics, the ever-increasing evidence base for humaninduced climate change and its impacts has provided an essential reference point of international climate talks. Institutionalized and internationally-anchored, the assessments of the IPCC provide a reputable and accepted source of information supported by thousands of scientists and adopted by member governments. ${ }^{64}$ In addition to the IPCC, hundreds of researchers present their findings at climate talks, launch publications, and identify areas for further research. In cooperation with companies, they present technological breakthroughs that help negotiators to assess the feasibility of climate goals. Experts also help delegations to understand technology, gain expertise and build confidence to formulate and implement more ambitious contributions, and to build interest group support to pursue them. ${ }^{65}$

Leveraging implementation capacity. Observers, in particular private actors, also stand for action as they possess the financial and operational agency needed to implement climate solutions. Non-State actors, in particular private corporations and financial organizations, will eventually drive much of the eventual innovation and implementation of climate measures. Among public actors, cities are often laboratories of policy innovation. They are also responsible for a significant share of public programmes that reduce GHG emissions and increase resilience. International organizations that assist developing countries with implementing mitigation or adaptation measures also hold

hold the endorsers of the NYDF accountable to their pledges (www.forestdeclaration.org), all accessed 5 July 2019 .

63 JW Kuyper, B-O Linnér and H Schroeder, 'Non-state actors in hybrid global climate governance: justice, legitimacy, and effectiveness in a post-Paris era' (2018) WIREs Climate Change 2018, 9:e497.

64 IPCC, 'Assessment Reports', https://www.ipcc.ch; accessed 4 July 2019.

65 S Chan, $\mathrm{H}$ van Asset, $\mathrm{T}$ Hale, K Abbott et al., 'Reinvigorating International Climate Policy: A Comprehensive Framework for Effective Nonstate Action' (2015) Global Policy 466-473. 
capacities and relevant resources to drive climate policy in client counties. ${ }^{66}$ However, most of the implementation of climate measures will fall on private actors, which will be responsible for producing technical innovations and pair those with the operational and financial capacities to implement climate solutions.

\section{Shifting Responsibilities to Non-State Actors}

While awareness raising, lobbying, and providing expertise are functions that describe outside influences on the regulatory core of the climate regime, leveraged implementation capacity offered by private and public actors is essential for achieving the ultimate goal of climate policy. While providing incentives for private action, that is, in the form of subsidies, reward schemes, certification, or regulation, falls traditionally into the responsibility of party States, integrating a call to action to non-parties into the framework of the Paris Agreement elevates this function to an international concern. It adds realpolitik to diplomacy.

Where public institutions are failing, private action is essential to fill the action gap. Countries with weak institutions and limited access to technology have limited ability to take measures, adopt and implement policies that reduce emissions and strengthen the resilience of national systems to the effects of climate change. Many lesser-developed countries also lack the institutions necessary to ensure that information is gathered and synthesized, warning systems are enabled, investments in public infrastructure are made, agricultural systems are strengthened and food security is ensured. Private (for-profit and non-for-profit) actors that are present in regions where public institutions are weak or missing can help to compensate for the lack of action, knowledge and regulation by public institutions. They can also generate data and often collect and analyse information more effectively than many government institutions.

The concerted action of private and public actors is necessary to produce the required environmental outcomes. Public actors have an interest in harnessing the financial power, expertise and technology advantages of the private sector. Corporations in turn prefer coordinated international action to unpredictable

66 K Abbott, J Green, and R Keohane, 'Organizational Ecology and Institutional Change in Global Governance' (2016) 70(2) International Organization 247-277. Many organizations, including the World Bank, FAO, and the International Civil Aviation Organization (ICAO), date back to the founding of the United Nations, but even the Global Environment Facility or the IPCC pre-date the UNFCCC. 
and fragmented regulation. This is particularly true for international initiatives which enable cooperation across borders and help to avoid free-riding of competitors. Recognizing this, the notion of partnerships has become all but ubiquitous at international climate meetings. ${ }^{67}$ Against the backdrop of a dynamic interplay based on pressure and coercion on one hand, and the offer of joint action and financial incentives of the other, cooperative action is often the only option for effective climate action. Action in smaller groups or 'clubs' of willing and enabled States that act in coordination with private partners can strengthen mitigation strategies and help reduce the dangers of free-riding for so-called coalitions of the willing. ${ }^{68}$

Private actors also spearhead action where public policy is slow or unlikely to emerge. Reaching international consensus on climate action remains a cumbersome and sluggish undertaking; and even where consensus has been reached, the rules are often ambiguous and vague. International rules, including the articles of the Paris Agreement, lack a level of definition that would allow them to be implemented without additional concretization. National level policy formulation, while faster than the forging of an international consensus, is not a speedy undertaking either. Experience shows that where private actors have decided to act, they are outpacing public action. ${ }^{69}$

Recognizing that non-State actors are essential agents of international climate policy, the Paris Agreement is built on a two-track or 'hybrid' governance system..$^{70} \mathrm{~A}$ formal track calls on parties to contribute to the overall climate goal formulated in Article 2 of the Agreement through 'nationally determined contributions' (Articles 3 and 4), and a non-State track centres on the

67 F Biermann, 'Beyond the Intergovernmental Regime: Recent Trends in Global Carbon Governance' (2010) 2 Current Opinion in Environmental Sustainability 284-288; JCS Andrade and JA Puppim de Oliveira, "The Role of the Private Sector in Global Climate and Energy Governance' (2015) 130(2) Journal of Business Ethics 375-387. The 2002 Johannesburg World Summit on Sustainable Development was the first summit to make partnerships between governments and private actors a core deliverable of the summit: United Nations, 'Johannesburg Declaration on Sustainable Development, From Our Origins to Our Future', Report of the World Summit on Sustainable Development, Johannesburg, South Africa, 26August-4 September 2002, UN Doc A/CONF.199/2O (2002), Chapter 1, Annex, para 26.

68 R Falkner, 'A Minilateral Solution for Global Climate Change? On Bargaining Efficiency, Club Benefits, and International Legitimacy' (2016) 14(1) Perspectives on Politics 87-101.

69 The response of the private sector to the incentives set by the Clean Development Mechanism is an example of acceleration of public policy through private action. The reduction in costs and deployment of renewable energy is another example of acceleration of action through private actors.

Described in detail in JW Kuyper, B-O Linnér and H Schroeder, above (n 63). 
'Non-State Actor Zone for Global Action', a programme that records and broadcasts actions by companies, cities, subnational regions, investors and civil society organizations to address climate change. The described weaknesses of a top-down State-centric system led to the integration of the non-State track as one of the strategies of the Paris Agreement to reduce the risk of failure.

This puts the UNFCCC Secretariat into a role of a conductor that 'orchestrates ${ }^{71}$ private action, and broker initiatives involving public and private entities. Multilateral processes and organizations increasingly rely on orchestration as the mode of governance as they attempt to steer the efforts of private and public actors through coordination and soft power. ${ }^{72}$ Orchestration is also the mode of operation for voluntary and open initiatives that lack a regulatory framework. Non-State actors drive many of such initiatives, which often take the form of transnational and public-policy networks or public-private or NGO-corporate partnerships, which complement functional gaps in global governance through multilevel and transnational collaboration. ${ }^{73}$

The UNFCCC Secretariat as conductor of the NAZCA orchestra relies on intermediaries (UN agencies, bilateral agencies, multi-stakeholder platforms, city and other networks, among others) for implementation and through calling on non-State actors can partly compensate for weak governance and lack of implementation capacities among State parties. ${ }^{74}$ It is therefore not surprising that the climate change initiatives listed under NAZCA are largely transnational, that is, they include more than one non-State or subnational actor; they follow public policy objectives; and they are arranged in a networked, as opposed to hierarchical, structure..$^{75}$ However, despite all good intentions, it remains uncertain how effective the pledged action under NAZCA will be. Initial assessments of a subset of pledged actions show their potential in

71 K Bäckstrand and JW Kuyper, 'The Democratic Legitimacy of Orchestration: The UNFCC, Non-State Actors, and Transnational Climate Governance' (2017) Environmental Politics 764-788; Chan et al., above ( $\mathrm{n} 65$ ).

72 KW Abbott, P Genschel, D Snidal, and B Zangl, 'Two Logics of Indirect Governance: Delegation and Orchestration' (2015) 46 British Journal of Political Science 719-729.

73 V Galaz, H Österblom, B Örjan and B Crona, 'Global Networks and Global Changeinduced Tipping Points' (2016) 16 International Environmental Agreements: Politics, Law and Economics 189-221. For the cases of deforestation in Brazil and Indonesia, see M Di Gregorioa, L Fatorelli, J Paavola et al., 'Multi-level Governance and Power in Climate Change Policy Networks' (2019) 54 Global Environmental Change 66-74.

74 Bäckstrand and Kuyper, above (n 71 ).

75 O Widerberg and P Pattberg, 'International Cooperative Initiatives in Global Climate Governance: Raising the Ambition Level or Delegitimizing the UNFCCC?' (2015) 6(1) Global Policy 45-56. 
contributing to NDC s but reveal large uncertainties as many initiatives are not quantifiable. ${ }^{76}$

In its 'broad then deep' approach to climate mitigation, ${ }^{77}$ the Paris Agreement invites all actors to be part of the compliance regime and trusts that over time the climate commitments become more ambitious and stronger. This transition away from a climate regime organized around binding obligations and targets for party States mirrors a broader shift towards private and public-private partnerships and collaborative governance arrangements that are often led by private initiatives. ${ }^{78}$ The transition from the regulated architecture of the Kyoto Protocol to the open system of the Paris Agreement acknowledges and integrates the 'groundswell ${ }^{79}$ of climate action into the treaty-based UNFCCC climate regime.

Considering this acknowledgement, the mechanisms that are included into the formal text of the Paris Agreement to harness private action remain eerily anchored into the climate governance of the last century. Article 6 of the Agreement seeks to stimulate cooperative approaches towards climate action, including those involving non-State actors, is based on the carbon market mechanisms of the Kyoto Protocol, but fails to create a demand for carbon credits. In the absence of formal emission reduction targets, clear regulatory signals that would mobilize public or private demand for verified emission reductions from a broader set of countries are lacking. ${ }^{80}$ The Kyoto Protocol anticipated an international system based on Governments translating international rules into national law, defining a consistent model of carbon pricing

76 J Graichen, S Healy, A Siemons et al., International Climate Initiatives - A Way Forward to Close the Emissions Gap? Initiatives' Potential and Role under the Paris Agreement, Discussion Paper, Climate Change 31/2016 (Umweltbundesamt, 2016).

77 D Bodansky, J Brunnée, and L Rajamani, International Climate Change Law (Oxford University Press, 2017) 209-224; CA Johnson, 'Holding Polluting Countries to Account for Climate Change: Is “Loss and Damage" Up to the Task?' (2017) 34 Review of Policy Research 50-67. The criticisms of US climate pundits reach back to the early 2ooos. See, e.g., D Victor, The Collapse of the Kyoto Protocol and the Struggle to Slow Global Warming (Princeton University Press, 2001).

78 Widerberg and Pattberg, above ( $\mathrm{n} 75)$; Andrade and Puppim de Oliveira, above (n 67).

79 Chan et al., above ( $\mathrm{n}_{5}$ ).

8o Advanced economies have so far failed to create 'adequate and predictable' demand or finance for verified emission reductions from mitigation action: $\mathrm{R}$ Janssen, 'Climate Finance Update: Climate Funds Announced for Africa' Energy in Demand (2017), https:// energyindemand.com/2017/08/11/latest-update-on-climate-finance-29/; accessed 5 July 2019 . 
that would give rise to a global carbon market. ${ }^{81}$ While carbon pricing through emission trading systems or carbon taxes remains a popular climate policy instrument, today's carbon pricing schemes are a mix of private and public, partly overlapping market segments. ${ }^{82}$ Old-style centrally-organized carbon market mechanisms may therefore not be the best means to help countries meet their NDCs and generate additional emission reductions. More effective ways will be needed to engage private sector actors in transnational climate initiatives and partnerships. ${ }^{83}$

The recognition of non-State action and the transition towards a hybrid multilateralism' 84 has left the two-governance track largely unconnected. So far, the interaction between the formal negotiations and NAzCA remains fairly sterile: the UNFCCC provides non-State actors a stage and legitimacy, but there is no way for such initiatives to feed back some of the positive dynamics they have created. ${ }^{85}$ Non-State actors do not have the option to make pledges formally recorded under the Paris Agreement (let alone be on par with the parties), and they lack both procedural rights and obligations that would extend the transparency framework to non-State initiatives. ${ }^{86}$ Feedback loops that would link private action to the transparency framework and the global stocktake under the Paris Agreement are missing. ${ }^{87}$ As the ongoing discussions on double counting situations - notably in the area of international aviation ${ }^{88}$ and voluntary offsetting 89 - show, there are direct repercussions. Offsets procured under the envisaged Carbon

81 S Bernstein, M Betsill, M Hoffmann and M Paterson, 'A Tale of Two Copenhagens: Carbon Markets and Climate Governance' (2010) 39(1) Millennium: Journal of International Studies $161-173$.

82 Ibid.

83 S Chan, R Falkner, M Goldberg, and H van Asselt, 'Effective and Geographically Balanced? An Output-based Assessment of Non-State Climate Actions' (2018) 18(1) Climate Policy 24-35.

84 JW Kuyper, B-O Linnér, H Schroeder, above (n 63).

85 L Hermwille, 'Making Initiatives Resonate: How Can Non-State Initiatives Advance National Contributions under the UNFCCC?' (2018) 18 International Environmental Agreements: Politics, Law and Economics 447-466.

86 C Streck, 'Public and Private Responsibility under the Post Paris Climate Regime' in M Leder and T Hickmann (eds), Festschrift Harald Fuhr (2019, in press); Streck et al., above (n 16).

87 L Hermwille, above ( $\left.\mathrm{n}_{5}\right)$.

88 L Schneider and S La Hoz Theuer, 'Environmental Integrity of International Carbon Market Mechanisms under the Paris Agreement' (2018) 19(3) Climate Policy 386-400.

$89 \quad \mathrm{M}$ von Unger, Freiwilliger Markt-Möglichkeiten und Herausforderungen für das Offsetting innerhalb der EU (Atlas Environmental Law Advisory, 2018), https://bit.ly/2E4c6Cd; accessed 4 July 2019 . 
Offsetting and Reduction Scheme for International Aviation or CoRsiA ${ }^{90}$ will run the risk of counting towards host country emissions levels and, thus, jeopardize ambition. The cut-off from the transparency and compliance framework leaves non-State actors with loose and ad hoc tools such as the climate tracking tool, ${ }^{91}$ outside any common, participatory design or verification process. The result raises concern both in terms of legitimacy ${ }^{92}$ as well as effectiveness. ${ }^{93}$

\section{Non-State Actors as Rule Makers}

The increasing prominence of non-State actors also impacts the formal and informal rule setting under the regime. Certainly, State parties remain the central node in the UNFCCC and in the agreements negotiated under its auspices. The UNFCCC provides the negotiation and organizational platform of the international climate regime. Following UNFCCC processes, first the Kyoto Protocol and then the Paris Agreement have been negotiated to define the operational context for the implementation of climate policies and measures. Jointly these agreements also define the purpose and goals of the collective effort, ${ }^{94}$ and set rules for accounting and reporting. ${ }^{95}$

The drafters of the Kyoto Protocol relied on private action in the implementation of the so-called 'Kyoto Mechanisms', which built flexibility into the compliance regime of the Protocol by allowing the emission reductions achieved through investments in projects outside of a country's boundaries to be counted against a party's target. Such a direct involvement of non-State actors in the implementation of a treaty has raised a number of legal questions around responsibilities, liabilities and legal protections. ${ }^{96}$ Where States

90 ICAO, Assembly Resolution A39-3: Consolidated statement of continuing ICAO policies and practices related to environmental protection-Global Market-based Measure (M вм) scheme, adopted at the 39th Assembly, 27 September-6 October 2016.

91 Global Climate Action, above (n 13).

$92 \quad$ K Bäckstrand and J Kuyper, above (n 71$)$.

93 S Chan, R Falkner, M Goldberg, and $\mathrm{H}$ van Asselt, above (n 83).

94 UNFCCC, above ( $\left.\mathrm{n}_{5}\right)$, Art 2; Paris Agreement, above ( $\left.\mathrm{n}_{1}\right)$, Art 2.

95 UNFCCC, above (n 5), Art 12; Kyoto Protocol, above (n 7), Arts 5, 7, 8; Paris Agreement, above (n 7 ), Art 13 .

96 C Streck and J Lin, 'Making Markets Work: A Review of CDM Performance and the Need for Reform' (2008) 19(2) European Journal of International Law 409-442; M von Unger and C Streck, 'An Appellate Body for the Clean Development Mechanism: A Due Process Requirement' (2009) 3(1) Carbon and Climate Law Review 31-44. 
include private entities directly in the implementation of treaties, they challenge the traditional, vertical model of international law where the usual approach in treaties is for commitments to be translated into domestic laws before they regulate private actors. Where treaties move from constitutional to regulatory action - for example, the in transition from the UNFCCC to the Kyoto Protocol ${ }^{97}$ - they often engage in activities beyond the reach of controls imposed by the public law, democratic apparatus, or other review structures of individual States. ${ }^{98}$ This involves rule-making and standard setting through subsidiary bodies or in co-creation with private entities. The CDM Executive Board, for example, is a subsidiary body of the Kyoto Protocol which has adopted rules and methodologies that are binding for project developers. Such methodologies are developed by private or public project sponsors and validated by accredited, private entities. Private entities are hence both vertical recipients of regulation as well as horizontal active collaborators in the development and approvals of standards.

The Paris Agreement does not directly regulate the private sector. Instead it invites all public and private actors alike to contribute to climate change mitigation and adaptation. While the Paris Agreement does not formulate a process that formalizes the participation of private entities in standard-setting, it provides space for transnational networks and initiatives that positively contribute to international and national rule making.

Global networks and initiatives set standards and define modes of implementation. In doing so, they contribute to international rule-setting which is increasingly less top-down and procedurally defined, giving way to a bottomup, fragmented and more complex set of rules. Non-State actors have evolved from rule-takers to rule-makers, ${ }^{99}$ especially in implementation initiatives undertaken through cooperative global networks. Through proactive devising of climate solutions, these networks have acquired a certain authority to shape current and future cooperative efforts. ${ }^{100}$

Networks and private initiatives participate directly and indirectly in the design and formulation of rules. Direct participation refers to the actual formulation of rules - while indirect influence becomes relevant where

97 Bodansky et al., above ( $\mathrm{n} 77)$, 208. They describe the UNFCCC as constitutive, the Kyoto Protocol as regulatory, and the Paris Agreement as constitutive.

$98 \quad$ Ibid 8.

99 Andrade and de Oliveira, above ( $\mathrm{n} 67)$. The evolution of private actors to rule makes is the main argument of the article.

100 JF Green and G Auld, 'Unbundling the Regime Complex: The Effects of Private Authority' (2017) 6(2) Transnational Environmental Law 259-284. 
non-State actors trigger government regulation. Self-regulatory initiatives have been described as 'private transnational regulatory organizations' 101 that are established and governed by actors from civil society or business, and engage directly in standard setting. Not all of these rule-setting initiatives draw on the support of formal organizations, and rule-making may be less formalized and more ad hoc. Common features of such decentralized regulation are that private rule-makers operate through markets, not through interstate negotiations or hierarchy; they adopt voluntary standards and rely on incentives such as consumer demand, reputational benefits, avoidance of mandatory regulation, and reduced transaction costs to induce participation and compliance. ${ }^{102}$

In the international climate governance, carbon measurement and reporting standards are examples of initiatives which bring NGOs and businesses together to formulate private standards. The 'Greenhouse Gas Protocol Corporate Accounting and Reporting Standard' created by the World Resources Institute and the World Business Council on Sustainable Development provides the basis for much of industry GHG measurement and reporting. ${ }^{103}$ Other examples of private standards include those that regulate the voluntary carbon markets, such as Verra's Verified Carbon Standard ${ }^{104}$ or the American Carbon Registry. ${ }^{105}$ The Climate Action Reserve by the State of California is an example for a sub-national carbon standard. ${ }^{106}$ Such rule making, which initially happens outside of international negotiations, can be linked to public action through the recognition of standards, taking them as a starting point for government action. ${ }^{107}$ Expertise generated through voluntary carbon market transactions has informed the CDM and vice versa. A network analysis of public and private offset standards has also shown that, overwhelmingly, private

\footnotetext{
101 Abbott et al., above (n 6).

102 Ibid.

103 JF Green, 'Private Standards in the Climate Regime: The Greenhouse Gas Protocol' (2010) 12(3) Business and Politics 1-37.

104 Verra, 'Verified Carbon Standard Program', https://verra.org/verra-standards-andprograms/; accessed 5 July 2019 .

105 See American Carbon Registry website, https://americancarbonregistry.org; accessed 5 July 2019 .

106 See Climate Action Reserve website, http://www.climateactionreserve.org; accessed 5 July 2019 .

107 See, for example, the resolution of the European Parliament on palm oil which recognized the value of certification of the Roundtable for Sustainable Palm Oil but asks for continuous enhancement of its stakeholder base and audit capacity. European Parliament, Resolution on palm oil and deforestation of rainforests (4 April 2017) 2016/2222(INI).
} 
standards are linked to CDM rules: roughly 80 percent of all private transnational carbon offset standards recognize those rules. ${ }^{108}$

Another example is standards that lead to reduced GHG and other environmental or social outcomes in the sourcing or manufacturing of goods. Corporate actors formulate standards as part of voluntary "self-regulation" and market initiatives. ${ }^{109}$ These standards can influence international and national public safeguards, provided that they are sufficiently stringent and credible. Beyond acting as safeguards, climate-friendly production standards that lead to a reduction of GHG have been proposed across all sectors (e.g., for cement production or freight logistics as mentioned above). Such production standards help to achieve climate goals often in the context of broader sustainability goals. An example for such private self-regulation is the criteria formulated by various 'roundtables'. These are global, multi-stakeholder initiatives driven by cooperation between NGOs and companies to advance the sustainability of products or processes, such as the Roundtable on Sustainable Palm Oill10 or the Global Roundtable for Sustainable Beef. ${ }^{111}$ Many of the roundtables develop and some certify the compliance of producers with sustainable production criteria. Certification as quality criteria has been relevant in public rule-making, where certification can be a legally required feature for a product to enter a market or receive special treatment. One such programme is the Indonesia-EU Voluntary Partnership Agreement, a legally binding trade agreement which requires all timber products entering the European Union market from Indonesia be certified as deforestation-free. ${ }^{112}$

Private regulation and standards often emerge where public authority fails to act or where private authority steps in and overcomes the political and institutional constraints of State actors. ${ }^{113}$ In the absence of a global regulated carbon accounting standards, private initiatives formulate their own rules; and procurement standards often serve as reference points for sectoral agreements. Private rules can also fill a temporary regulatory gap until governments become active. Corporations prefer operating in the certainty of wellregulated markets that are backed by strong institutions and legal systems. The

\footnotetext{
108 Abbott et al., above (n 6).

109 Andrade and de Oliveira, above (n 67).

110 Roundtable on Sustainable Palm Oil, 'About', https://rspo.org/about; accessed 2o July 2018.

111 See the Global Roundtable for Sustainable Beef website, https://grsbeef.org/; accessed 20 July 2018.

112 EU FLEGT Facility, 'Background: The Indonesia-EU Voluntary Partnership Agreement' (2017), http://www.euflegt.efi.int/background-indonesia; accessed 20 July 2018.

113 Green and Auld, above (n 100).
} 
existence of such systems reduces transaction costs and ensures predictable operating conditions. Periods of prolonged regulatory insecurity are bad for business. The absence of public rules combined with the recognized need to take action has driven private or private-public initiatives to formulate private standards. Standards can help to level the playing field among competitors, increase the quality of a product, or reduce the risk associated with a particular activity. Private standards often coexist with public standards and stand in a dialogue with each other pushing for continuous elaboration, improvement, and advancement.

Standards that apply across jurisdictions and to various private initiatives help to ensure a certain quality and comparability of action (e.g., through private certification standards). The combination of data collection, implementation of projects and programmes, the agreement on standards, and the building of capacities among local governments, is essential to ensure transformation and effective climate action on the ground. The involvement of private actors in information gathering and exchange increases access to knowledge and expertise, including the identification of mitigation options, understanding cost implications, and receiving emissions data. Information diffusion and networking is a common activity of multi-stakeholder initiatives, ${ }^{114}$ and is essential to inform transnational standard-setting and international regulation.

The Paris Agreement encourages through its non-State actor track of action to engage in transnational and global initiatives. As these initiatives set their own rules, they fill a regulatory and action gap left by States. This provides them with a great role in the international climate regime and inherently increases non-State actors' ability to effect change on an international scale. ${ }^{115}$

Accountability Challenges and Risks

However, a de facto delegation of agency to non-State actors also poses questions of legitimacy, accountability and regulatory control. ${ }^{116}$ The climate regime's increasing reliance on private action raises questions with regards

\footnotetext{
114 Widerberg and Pattberg, above (n 6o).

115 S Herman, 'The Paris Climate Agreement: Harbinger of a New Global Order' (2019) 1(3) Swarthmore International Relations Journal 3-18.

116 R Sullivan and A Gouldson, 'The Governance of Corporate Responses to Climate Change: An International Comparison' (2017) 26(4) Business Strategy and the Environment 413-425.
} 
to the legitimacy of action and the democratic deficit of the global climate regime. ${ }^{117}$ The issue arises as international and transnational initiatives often lack a direct link that ties them to democratic institutions and processes of oversight and accountability. Government agencies in democratic regimes are held to account through periodic elections. Even though the electorate is separated through various levels of delegation from international climate negotiators, it still provides an important source of legitimacy that many transnational or networked climate initiatives are missing. However, direct accountability to the public becomes more abstract and less real where the negotiations are very complex and very hard for outsiders to understand. In these cases, democratic legitimacy is only one source of legitimacy and other mechanisms have to hold the various strands of the climate regime accountable. ${ }^{118}$

Generally, accountability is a multidimensional phenomenon and democratic authorization is only one source of legitimacy. ${ }^{119}$ As long as 'some actors have the right to hold other actors to a set of standards, to judge whether they have fulfilled their responsibilities in light of these standards, and to impose sanctions if they determine that these responsibilities have not been met'120 then there can be some basic level accountability. This accountability can provide the climate processes with a degree of legitimacy.

Transparency and due process requirements are essential elements of international accountability as they enable NGO s and the media to check and monitor State and private action taken under the climate regime. The extent to which they can fulfil their role depends on access to information through public disclosure. Disclosure leads to transparency which can help to establish legitimacy and build trust among the stakeholders involved. ${ }^{121}$ Transparency, monitoring and tracking of progress are essential to evaluate the aggregate impact of State mitigation efforts and the multitude of initiatives that contribute to these efforts. ${ }^{122}$ Aware of the need to strengthen transparency to

\footnotetext{
117 Bäckstrand and Kuyper, above (n 71), 5 .

118 RO Keohane and JS Nye Jr, Between Centralization and Fragmentation: The Club Model of Multilateral Cooperation and Problems of Democratic Legitimacy (Kennedy School of Government, Harvard University, Faculty Research Working Papers Series, RWPO1-004, 2001) 12 .

119 Ibid.

120 RW Grant and RO Keohane, 'Accountability and Abuses of Power in World Politics' (2005) 99(1) American Political Science Review 29-43.

121 World Resources Institute, 'Submission from World Resources Institute on the Roadmap for Global Climate Action' (1 August 2016), http://unfccc.int/files/parties_observers/ submissions_from_observers/application/pdf/649.pdf; accessed 5 July 2019.

Bäckstrand and Kuyper, above (n 71), 17.
} 
compensate for the absence of binding mitigation goals and a strong compliance mechanism, the Paris Agreement formulates in Article 13 an 'enhanced transparency framework for action and support' that aims at providing a clear understanding of mitigation action and available climate finance. Parties will have to collect and make available information necessary to track progress made in implementing and achieving their NDC and keep track of their emissions in national inventory reports. ${ }^{123}$

However, the transparency rules of the Paris Agreement do not extend to initiatives presented in the NAZCA and it will be hard to assess whether private pledges are implemented and their goals fulfilled. ${ }^{124}$ The UNFCCC Secretariat has been tasked to orchestrate non-State activities but it has not been given any tools to effectively control and manage these activities. ${ }^{125}$ The Paris Agreement would increase the legitimacy of voluntary, multi-stakeholder and transnational climate action if it would not only require governments but also nonState actors to report on implementation progress. By listing their activities on the UNFCCC/NAZCA website, private actors benefit from the reputation and exposure granted by the international process. If this is not counterbalanced by a requirement to disclose and report on progress, the Paris Agreement risks becoming a marketing tool for non-State actors where non-action remains unpunished and unsanctioned.

The increasing influence of private actors on regulatory processes also poses a risk to the public authority and the legitimacy of rule-makers. Within limits, the undue influence of one group of stakeholders on regulatory processes can be counterbalanced by ensuring more even access to regulatory processes by a broad set of interest groups. For example, the role of businesses can be counterbalanced by providing environmental and other NGOs equal access to policy makers. ${ }^{126}$ However, private sector participation is also often limited to larger, multinational firms that take a more active role in engaging at the international level than smaller and medium-sized companies that largely remain rule-takers. ${ }^{127}$ Being less vocal and less powerful, public actors also fail to effectively represent the interests of smaller actors. Where public entities

\footnotetext{
123 Paris Agreement, above ( $\mathrm{n} 7)$, Art 13 $(5,7,9)$.

124 Bäckstrand and Kuyper, above (n 71), 17.

125 For more detail of accountability under the Paris Agreement, see Bäckstrand and Kuyper, ibid.

126 Andrade and Puppim de Oliviera, above (n 67), give the example of organized negotiations and balanced the discussions of the International Labour Organization that provide rule-making with legitimacy.

127 Ibid.
} 
engage with corporations in transnational initiatives, allowing access to NGO s can help to increase the accountability of action outside of the formal policymaking processes. The increasing willingness of corporations to engage with NGO s provides a chance to influence private interests towards higher environmental standards. However, it also comes with the risks that NGOs get entangled in conflict of interests and lose their ability to hold businesses independently accountable. ${ }^{28}$

Concerns have also been raised with respect to the increasing influence of private standards which help to fill regulatory gaps where public action is slow, absent or in ineffective. Some authors have directly criticized the lack of integrity and transparency of private carbon standards. ${ }^{129}$ Considering that the most wide-spread private carbon standards are managed or closely monitored by NGO partners, it is doubtful whether they are indeed less transparent than regulated mechanisms like the CDM. ${ }^{130}$ Private standards that operate under national laws and award the due process rules of such laws often provide protection that internationally-governed rule systems such as the CDM are lacking. In the context of the Kyoto Protocol, international bodies (e.g., the CDM Executive Board) directly regulated private entities without awarding them the protection and rights of national administrative procedures. ${ }^{131}$ To ensure that private actors enjoy due process protection under international regimes, public standards should be embedded in the rule of law and good governance. Private standards can test rules and fill gaps, but governments remain essential in ensuring the implementation of climate change policies across sectors, regions and populations. Only governments set out to ensure full inclusion of poorer parts of the population into climate change regulation, including measures that increase resilience. It is also government regulation that creates additional incentives to enable private actors to adopt and scale climate-friendly technologies where intrinsic motivation is not strong enough to trigger action.

128 T Hickmann and B Prem, 'Von Gegnern zu Partnern? Vom Verhältnis von NGOs und Unternenhmen in der internationalen Klimapolitik' (2018) 21-23 Aus Politik und Zeitgeschichte 48-54.

$129 \mathrm{~J}$ Fuessler, M Herren, A Wunderlich et al., Market Mechanisms: Incentives and Integration in the Post-2020 World (INFRAs, 2015), https://climatefocus.com/sites/default/files/ Market\%2oMechanisms\%2oIncentives\%2oand\%2oIntegration\%2oin\%2othe\%2o Post $\% 202020 \% 20$ World.pdf; accessed 2 October 2020.

130 The most widely used standard is the Verified Carbon Standard. For its operating rules see Verra, above (n 104).

131 On the challenges of global regulatory governance and the role of global administrative law, see B Kingsbury, 'Introduction' (2011) 3 The World Bank Legal Review 3-33. 
Finally, the increasing reliance on private action can also serve as an excuse for governments to delay climate policy and measures, ${ }^{132}$ and private action is unlikely to be sufficiently ambitious to generate mitigation action at a speed and level that is already needed. Not all, but many private initiatives remain fuelled by the threat of regulation and emission controls. ${ }^{133}$ If private action waters down or delays important public sector rules, the overall benefits of private action may be nullified. It is therefore essential that private action is embedded into government action, private actors are held accountable for their action, and governments take the ultimate responsibility for international climate goals to be met.

In sum, the issue of legitimacy is a sensitive and much debated issue of network governance. Acknowledging the accountability challenges is essential, but no argument to move back to State-monopolistic governance or suppress private initiative. Instead legitimacy should inform the design of global NAZCA initiatives. Being aware of the risks that come with an increasing reliance of informal arrangement to achieve the goals of the Paris Agreement allows their mitigation, for example, by including NGO partners, increasing the degree of formalization over time, ensuring transparency and linking the efforts to private and public accountability initiatives. At the end, legitimacy is to be balanced with efficiency goals, and an issue as multifaceted and complex as climate change demands multisectoral and urgent action. ${ }^{134}$

Whereas the Kyoto Protocol harnessed private action, the Paris Agreement unleashes it - or at least it tries to do so. The formal empowerment of private action through the Paris Agreement, the creation of NAzCA and the courting of private actors by multilateral institutions and governments, is a reaction to the recognition of the role of the power and influence that private actors yield

132 S Chan, C Brandi and S Bauer, 'Aligning Transnational Climate Action with International Climate Governance: The Road from Paris' (2016) 25(2) RECIEL 238-247; see also F Miraftab, 'Public-Private Partnerships: The Trojan Horse of Neoliberal Development? (2004) 24(1) Journal of Planning Education and Research 89-101.

133 T Hickmann, 'Voluntary Global Business Activities and the International Climate Negotiations: A Case Study of the Greenhouse Gas Protocol' (2017) 169Journal of Cleaner Production 94-102.

134 On networked governance and the challenge of complex global problems, see Galaz et al., above (n 73). 
internationally and how essential these attributes are for the transformational global change that climate change requires.

Effective climate policy requires transformational change in the world's economies and management of natural resources. Private actors are essential agents of this change. They develop and own much of the technologies that enable the necessary change. They can also mobilize the required investments. While the relationship between public and private actors remains complicated, cooperation between policy makers and private actors is essential to define adequate responses to climate change.

Facilitated by international organizations or NGOs that push private and public actors into action, non-State actors have not only increased in numbers but also dramatically improved their ability to participate in the political system governing climate change. ${ }^{135}$ Limited initially to traditional lobbying (and more often than not a motivation to avoid regulation) private authority has expanded first to an active participation in shaping carbon markets ${ }^{136}$ and later to engagement in a multitude of multi-sectoral commitments, networks, partnerships and pledges. ${ }^{137}$ Such pledges, while non-binding in nature, create a forum for collective action. Through their publication they also allow civil society to hold participants and endorsers accountable towards progress, beyond government pledges and individual company policies. ${ }^{138}$ Ideally, such transparent non-State engagement results in productive cooperation and co-governance.

Today's international climate regime is characterized by clusters of vertical and horizontal regulation. Clusters exist vertically between supranational, international, national and subnational layers of authority. ${ }^{139}$ As recipients of regulation, non-State actors traditionally interact with governments vertically. However, in innovative climate partnerships and global networks, they meet governments in horizontal constellations, where they develop their own rules and standards that others may choose to follow; they are no longer merely complying with the directives of States, ${ }^{140}$ but actively shaping the system. In a continuous process

\footnotetext{
135 Biermann, above (n 67).

136 Green and Auld, above (n 10o).

137 For example, the New York Declaration on Forests (NYDF) brings together more than 190 governments, corporations, NGOs and indigenous peoples' organizations that have collectively endorsed ten goals that aim to protect forests and end natural forest loss by 2030 . See the NYDF website, http://nydfglobalplatform.org; accessed 5 July 2019.

138 For the NYDF, see annual progress reports at http://forestdeclaration.org; accessed 20 July 2018.

139 Biermann, above (n 67).

140 Bäckstrand et al., above (n 9), 568.
} 
of increased influence, non-State actors have moved from outside influencers to agents of implementation that often define their own rules.

This development bears risks in relation to regulatory power and legitimacy, but it also increases the chance that the goals of the Paris Agreement will be met. By empowering private actors, national governments may see room to adjust their ambitions upward when they take into account non-State and subnational actions. ${ }^{141}$ By linking the two-governance tracks of the Paris Agreement, Parties may increase the effectiveness of both tracks. They can encourage and reward private action, and ensure systems that hold private and public actors accountable where they fail to deliver on their pledges. NDCs and NAZCA partnerships can also be developed in a cooperative manner, under the umbrella of cooperative approaches under Article 6 of the Paris Agreement or independently.

While the private buzz holds great potential, it is important that governments do not become complacent and overly reliant on non-governmental action. Private action and networks cannot make up for governments failing to act. Private action alone is unlikely to rise to the level of ambition needed for the Paris temperature goals to be met. It is unfortunate that in many cases government action is less ambitious than private action. However, outside of an enabling framework, interests among non-State actors can become idiosyncratic and unstable. Despite its shortcomings, the agency of governments remains essential to uphold trust in action. Private initiatives can pioneer public regulation and step in where action is missing. But their rule-setting activities are interim in nature, acting more like a placeholder than a replacement. With the Paris Agreement, governments established a framework for action. They eventually have to fill it.

In sum, a regime that puts emphasis on decentralized public and private action - as the climate regime increasingly does - has to continuously assess progress and evaluate the effectiveness of the various strategies that contribute to the overall effectiveness of the regime. The regulatory framework supporting non-State action has to be evaluative, incorporating benchmarking and review and follow-up procedures beyond mere passive registration, ${ }^{142}$ to ensure full accountability of those that pledged action. It is essential that the international climate regime, for example, through NAZCA, not only provides limelight and an opportunity to showcase action, but supports private as much as public actors in their implementation efforts on one hand, and holds them accountable for action on the other.

\footnotetext{
141 Chan et al., above (n 132).

142 Chan et al., above ( $\mathrm{n}_{5}$ ).
} 